JKPS: ل_urnal Kesejahteraan dan Pelayanan Susial http://ojs.uhho.ac.id/index.php/JKPS/index

ISSN: 2716-3857 (Online)

\begin{tabular}{l|l|l|l|l}
\hline Volume 2 & Nomor 1 & Mei (2021) & DOl: http://dx.doi.org/10.52423//kps.v2i1.18174 & 72-85 \\
\hline
\end{tabular}

\title{
POLA ASUH KELUARGA SINGLE PARENT DALAM MENDIDIK ANAK (Studi Di Desa Masara Kecamatan Napano Kusambi Kabupaten Muna Barat)
}

\author{
Dewi krisnawati ${ }^{1}$, Ratna Supiyah ${ }^{2}$, Bahtiar $^{3}$ \\ 123Jurusan Sosiologi FISIP Universitas Halu Oleo, Kendari, Indonesia \\ 1Email korespondensi: dewikhrisnawaty8@gmail.com
}

\begin{abstract}
ABSTRAK
Penelitian ini bertujuan untuk mengetahui pola asuh keluarga single parent dalam mendidik anak di Desa Masara Kecamatan Napano Kusambi Kabupaten Muna Barat.Dalam penelitian ini 8 informan. Adapun kriteria informan tersebut yaitu: orang tua tunggal atau single parentdalam mendidik anak-anaknya di Desa Masara Kecapatan Napano Kusambi Kabupaten Muna Barat. Metode yang digunakan dalam penelitian ini adalah metode penelitian deskripsif kualitatif.Pengumpulan data dalam penelitian dengan observasi, wawancara langsung, dokumentasi, dan studi kepustakaan. Hasil penelitian menunjukan bahwa keluarga single parent dalam mendidik anak di Desa Masara Kecamatan Napano Kusambi Kabupaten Muna Barat menggunakan tiga pola asuh yaitu pola asuh permissif, pola asuh demokratis dan pola asuh otoriter.Pola asuh permissif dapat diartikan sebagai pola perilaku orang tua dalam berinteraksi dengan anak untuk melakukan apa yang inggin di lakukan tanpa mempertayakan. pola asuh demokratis menurut Baumrind dan Black dari hasil penelitianya menemukan bahwateknik-teknik asuhanorang tua demokratisyang menumbuhkan keyakinandan percayaan diri maupun mendorong tindakan- tindakan mandiri membuat keputusan sendiri akan berakibat munculnya tingka laku mandiri yang bertanggung jawab. Sedangkan pola asuh otoriter yaitu pola asuh orang tua menerapkan aturan dan batasan yang mutlak harus ditaati, tanpa memberi kesempatan pada anak untuk berpendapat, jika anak tidak mematuhi akan diancam dan dihukum. Faktor pendorong penerapan pola asuh keluarga single parentdalam mendidik anak di Desa Masara Kecamatan Napano Kusambi Kabupaten Muna Barat yaitu motivasi orang tua.Sedangkan faktor penghambat penerapan pola asuh keluarga single parent dalam mendidik anak di Desa Masara Kecamatan Napano Kusambi Kabupaten Muna Barat yaitu sikap orang tua, perilaku yang di contoh, kesadaran diri, komunikasi.
\end{abstract}

Kata Kunci: Pola Asuh Keluarga,Single Perent, Mendidik Anak. 


\begin{abstract}
This study aims to determine the parenting style of single parent families in educating children in Masara Village, Napano Kusambi District, West Muna Regency. In this study 8 informants. The criteria for these informants are: single parent or single parent in educating their children in Masara Village, Napano Kusambi District, West Muna Regency. The method used in this research is descriptive qualitative research method. Collecting data in research by observation, direct interviews, documentation, and literature study. The results showed that single parent families in educating children in Masara Village, Napano Kusambi District, West Muna Regency used three parenting styles, namely permissive parenting, democratic parenting and authoritarian parenting. Permissive parenting can be interpreted as a pattern of parents' behavior in interacting with children. to do what you want to do without questioning. According to Baumrind and Black, democratic parenting styles from the results of their research found that democratic parenting techniques that foster self-confidence and self-confidence as well as encourage independent actions to make their own decisions will result in the emergence of responsible independent behavior. Meanwhile, authoritarian parenting is the parenting style of parents applying rules and limitations that absolutely must be obeyed, without giving the child the opportunity to argue, if the child does not comply, they will be threatened and punished. The driving factor for the implementation of single parent family parenting in educating children in Masara Village, Napano Kusambi District, West Muna Regency is the motivation of parents, while the inhibiting factor for the application of single parent family parenting in educating children in Masara Village, Napano Kusambi District, West Muna Regency is the attitude of parents Examples of behaviors, self-awareness, communication.
\end{abstract}

Keywords: Family Parenting, Single Perent, Educating Children.

\title{
PENDAHULUAN
}

Keluarga inti pada umumnya dibangun berdasarkan ikatan perkawinan. perkawinan menjadi pondasi bagi keluarga oleh karena itu Ketika sepasang manusia menikah akan lahir keluarga yang baru.keluarga batih biasanya terdapat dalam masyarakat yang memandang penting pasangan,keluarga batih biasanya terdapat dalam masyarakat yang memandang penting hubungan kekerabatan.

Keluarga merupakan suatu kelompok masyarat yang dibentuk dengan ikatan pernikahan keluarga juga merupakan konsep yang bersifat multidimensi, dari segi keberadaan keluarga dapat dibedakan menjadi dua yaitu keluarga inti dan keluarga batih. keluarga inti adalah keluarga yang didalamnya hanya terdapat tiga sisi sosial yaitu suami/ayah, istri/ibu dan anak kandung (Lee, 1982) adapun keluarga batih adalah keluarga yang didalamnya menyertakan posisi lain ketiga posisi di atas.Sebagai single parent atau orang tua seorang janda tidaklah mudah, karena menjalankan kehidupan sehari-hari 
seorang diri tanpa kehadiran pasangan hidup.Orang tua seorang janda secara otomatis mengalami perubahan-perubahan tanggung jawab didalam keluarga.

Di Indonesia, keluarga single parent ibu sebagai orang tua memiliki jumlah persentase yang besar dengan 80 persen dari 24 persen kepala keluarga perempuan merupakan ibu tunggal survei penduduk antar sensus badan pusat statistic (SUPAS BPS 2015). Dari data tersebut fenomena keluarga single parent dalam sebuah rumah tangga tentu tidak mudah, terlebih bagi seorang ibuyang mengasuh anaknya hanya seorang diri karena suaminyameninggal dunia.Hal tersebut membuhtukan perjuangan dan pola asuh yang cukup berat untuk membersakan anak-anaknya dan memenuhi kebutuhan hidup dalam keluarganya yang lebih memberatkan diri adalah anggapan-anggapan dari lingkungan yang sering memojokan para ibu single parent, hal tersebut bisa jadi akan mempengaruhi kehidupan dan perkembangan anak karena tidak lengkapnya orang tua. Keluarga single parent bukanlah sebuah fenomena yang langka meski stigma mengenai keluarga ini cenderung masih negatif sebagaimana disampaikan oleh pendiri SPINMOTON (Single Parents Indonesia In Mation), Yasin bin Malenggang, di Vemale.com pada tanggal 27 Desember 2017.

Mendidik anak merupakan salah satu tugas mulia yang tidak lepas dari berbagai halangan dan tantangan. Meskipun demikian mendidik anak adalah harapan dan cita-cita para orang tua untuk dapat mengembangkan potensi anak semaksimal mungkin agar anak tersebut mampu dan berhasil dalam memenuhi tugas-tugas yang berlaku pada usia 11-13 tahun dapat melampaui jenjang pendidikan sekolah dasar sehingga bisa memahami ajaran atau nasehat dari orang tuanya, sampai pada masa remaja dapat menerapkan nilai-nilai moral dengan baik secara bertahap anak mampu untuk menyesuaikan diri terhadap lingkungannya (Gunarsa, 2008:3-4). Hal tersebut merupakan harapan nyata orang tua dalam mendidik anak.

Anak merupakan amanah yang dititipkan oleh orang tua untuk di didik menjadi manusia yang bermanfaat dan mempunyai perilaku yang baik. tentuhnya anak itu berperilaku baik, maka yang dilihat adalah cara orang tua dalam mendidik anaknya. Dalam masa perkembangan seorang anak membutuhkan suasana keluarga yang hangat dan penuh kasih sayang maka 
seorang janda bisa mendidik anaknya dengan baik. Seorang janda pada saat ini tidak lagi hanya sebagai seorang yang bekerja di rumah tetapi harus mampu memposisikan diri sebagai kepala rumah tangga. Perubahan yang terjadi pada keluarga single parent awalnya menjadi seorang ibu atau istri kini berubah menjadi ibu sekaligus sebagai kepala rumah tangga yang tidak hanya mendidik, merawat, mengasuh anak- anaknya tetapi kini harus mencari nafkah untuk menunjang kehidupan mereka.

Seperti Fenomena yang terjadi di Desa Masara Kecamatan Napano Kusambi Kabupaten Muna Barat adalah sebagian besar keluarga single parent yang terjadi akibat meninggal dunia. di Desa ini terdapat beberapa orang tua keluarga single parent atau janda yang bekerja sebagai petani atau pedagang dengan membesarkan anak-anaknya tanpa pasangan, keluarga single parent berpengaruh terhadap penanaman nilai-nilai sosial anak, dimana anak-anak yang di asuh oleh orang tua single parent (ibu) akan berbeda dengan penananman nilai-nilai sosialnya dengan anak yang di asuh oleh orang tua lengkap.

Ketika diasuh oleh keluarga single parent maka tidak menutup kemungkinan, sebagian anak akan melakukan peilaku yang menyimpang seperti suka membantah dan melawan orang tua, sering menggunakan katakata yang kurang sopan, bahkan sampai memakai obat-obatan terlarang. Perilaku menyimpang yang dilakukan maupun orang tua mengabaikan pendidikan anaknya, khususnya dalam menanamkan nilai-nilai agama (Canete \& Pandey, 2020) akibatnya anak kurang mendapat perhatian, kasih sayang bimbingan dari orang tua. Memang keluarga merupakan lingkungan sosial terkecil yang memiliki tanggung yang sangat besar untuk mendidik dan membentuk kepribadian seorang individu. Di dalam keluarga juga memberikan motivasi khususnya orang tua kepada anak untuk memberi dorongan agar anak menjadi anak yang baik dan soleha karena hubungan orang tua dengan anak adalah hubungan hakiki secara psikologis maupun mental spiritual. Namun sebagai single parent di Desa Masara masih kurang memberikan motivasi tersebut.

Seorang janda atau single parent sebagai kepala keluarga sangatlah penting, dimana dia akan melakukan tugas gandahnya (Ahriani dkk., 2020) 
sebagai kepala keluarga yang memiliki kewajiban untuk pendidikan dari sekolah dasar hingga perguruan tinggi yang di mana di Desa Masara Kecamatan Napano Kusambi Kabupaten Muna Barat dianggap suatu hal yag membanggakan apabila berhasil menyekolahkan anak hingga perguruan tinggi terlebih lagi dia merupakan orang tua single parent atau di sebut janda pembahasan mengenai mendidik anak tidak bisa di anggap remeh, karena melalui anak segala cita-cita orang tua di wujudkan. Seperti single parent yang ada di Desa Masara, terdapat 8 keluarga single parent, dari ke 8 single parent tersebut bekerja mendidik anak umur 11-13 tahun dengan seorang diri. Dimana dari hasil observasi bahwa single parent di Desa Masara, Kecamatan Napano Kusambi Kabupaten Muna Barat mampu memposisikan dirinya sebagai orang tua ataupun ibu bagi anak-anaknya. Beberapa single parent di Desa ini mampu menyekolahkan anaknya hingga sampai pada level strata satu.

Dengan demikian, maka ada dua rumusan masalah yang didapatkan dalam penulisan ini adalah sebagai berikut:

1. Bagaimana pola asuh keluarga single parent dalam mendidik anak di Desa Masara Kecamatan Napano Kabupaten Muna Barat?

2. Faktor-faktor apa yang mendorong dan menghambat penerapan pola asuh keluarga single parent dalam mendidik anak di Desa Masara Kecamatan Napano Kusambi Kabupaten Muna Barat?

\section{METODE PENELITIAN}

Penelitian ini telah dilaksanakandi Desa Masara Kecamatan Napano Kusambi Kabupaten Muna Barat.Penentuan lokasi penelitian berdasarkan beberapa pertimbangan terkait dengan permasalahan yang akan diteliti yang berkaitan dengan beberapa fakta mengenai keberadaan beberapa single parent. Dalam menentukan informan dilakukan dengan menggunakan teknik purposive sampling, artinya sampel sengaja dipilih berdasarkan kriteria yang telah ditetapkan sesuai dengan tujuan penelitian.Peneliti telah menentukan informan menjadi sumber penelitiannya dengan anggapan atau pendapatnya sendiri adalah masyarakat dengan jumlah 8 orang informan.

Jenis data yang akan digunakan dalam penelitian ini yakni data kualitatif dan data kuantitatif, jenis data kualitatif yang sifatnya tertulis 
maupun lisan dalam rangkaian kata-kata atau kalimat dalam penelitian ini dan Data kuantitatif digunakan untuk menggambarkan jumlah penduduk dan letak geografis wilayah yang akan diteliti. Adapun sumber data dalam penelitian ini yaitu data primer dan data sekunder, data primer yang didapat dalam penelitian ini yaitu hasil wawancara menggunakan panduan wawancara yang disusun oleh peneliti guna mendapatkan data terhadap informan di Desa Masara Kecamatan Napano Kusambi Kabupaten Muna Barat, dan Data sekunder yaitu data yang telah dikumpulkan untuk maksud selain menyelesaikan masalah yang sedang dihadapi. Data ini dapat ditemukan dengan cepat. Dalam penelitian yang menjadi sumber data berupa literatur, artikel, jurnar serta situs di internet yang berkenaan dengan penelitian yang dilakukan. Pengumpulan data yang digunakan dalam penelitian ini adalah: observasi wawancara, dan Studi dokumen dan untuk menganalisis data yang sudah didapat, peneliti menggunakan teknik analisis data sebagai berikut: reduksi data penyajian data dan penarikan kesimpulan (Damsid dan Upe, 2010).

\section{HASIL PENELITIAN DAN PEMBAHASAN}

Single parent (janda) adalah suatu keluarga yang dipimpin oleh seorang pemimpin saja (orang tua seorang janda) maupun ibu saja dan keluarga single parent yang dimaksud disini adalah keluarga yang dikepalai seorang janda yang telah memiliki anak dari pernikahannya dan single parent tersebut merawat, mendidik, mengasuh dan membesarkan anaknya seorang diri, di sebabkan karena kematian.

Menurut Hurlock (1999:19) single parent adalah orang tua yang telah menjanda bertanggung jawab untuk memelihara anak-anak tanpa bantuan pasanganya single parent adalah orang tua seorang janda di mana orang tua memiliki pengertian yang sangat luas.Seperti yang di kemukakan oleh Hammer dan Turner yang mengartikan istilah single parent sebagai orang tua seorang janda yang masih memiliki anak yang masih tinggal satu rumah dengannya. Setelah kematian atau penceraian. Menurut Duvall \& Miller (1985) menyatakan bahwa orang tua (single parent) adalah orang tua yang secara 
sendirian membersarkan anak-anaknya tanpa kehadiran, dukungan, dan tanggung jawab pasagannya.

\section{Pola asuh Keluarga Single Parent}

Pola asuh merupakan sikap orang tua dalam berinteraksi dengan anakanaknya.Sikap orang tua ini meliputi cara orang tua memberikan aturanaturan, hadiah maupun hukuman, cara orang tua menunjukkan otoritasnya, dan cara orang tua memberikan perhatian serta tanggapan terhadap anaknya.Keluarga single parent (janda) adalah suatu keluarga yang dipimpin oleh seorang pemimpin ibu saja dan keluarga single parent yang dimaksud disini adalah keluarga yang dikepalai orang tua tunggal yang telah memiliki anak dari pernikahannya dan keluaraga single parent tersebut merawat, mendidik, mengasuh dan membesarkan anaknya seorang diri, di sebabkan karena kematian. Salah satu fenomena yang banyak dijumpai dalam masyarakat kita saat ini dan merupakan salah satu perubahan yang terjadi dalam lembaga keluarga adalah semakin meningkatnya keberadaan orang tua janda (single parent), yang dalam hal ini bisa berarti seorang ibu membesarkan anaknya sendirian (single mother).Dari Hasil Penelitian Diatas menunjukkan bawasannya keberadaan atau eksistesi seorang single perent sangatlah penting ditenggah-tenggah keluarga, kehilanga seorang pasangan/suami tidaklah membuat sorang single perent pantang semangat dalam membersarkan anakanaknya tanpabantuan siapapun.

\section{Pola Asuh Keluarga Single Parent Dalam Mendidik Anak di Desa Masara} Kecamatan Napano Kusambi Kabupaten Muna Barat.

Pola asuh adalah merupakan sejumlah model atau bentuk perubahan ekspresi dari orang tua yang dapat mempengaruhi potensi yang melekat pada diri individu dalam upaya memelihara, merawat, membimbing, membina dan mendidik anak-anaknya baik yang masih kecil ataupun yang belum dewasa agar menjadi manusia dewasa yang mandiri dikemudian hari. Pembentukan anak bermula atau berawal dari keluarga. Pola asuh orang tua terhadap anakanaknya sangat menentukan dan mempengaruhi keperibadian serta perilaku anak. Anak menjadi baik atau buruk semua tergantung dari pola asuh orang 
tua dalam keluarga, maka pola asuh dibedakan menjadi beberapa macam yaitu sebagai berikut :

\section{Pola Asuh Permissif}

Pola asuh permissif dapat diartikan sebagai pola perilaku orang tua dalam berinteraksi dengan anak untuk melakukan apa yang ingin dilakukan tanpa mempertayakan. Pola asuh ini tidak menggunaka aturan-aturan yang ketat bahkan membimbing pun kurang diberikan penuh dan anak di ijinkan untuk memberi keputusan untuk dirinya sendiri, tanpa pertimbangan orang tua dan berperilaku tanpa ada yang di inginkan tanpa ada kontrol dari orang tua. Berdasarakan ungkapan para informan dapat disimpulkan bahwa pola asuh anak yang melekat pada single parent ini adalah pola asuh premisif, yang artinya orang tua masi menerimah apa yang menjadi keputusan si anak. Namun di sisi lain orang tua tetap mengontrol keberadaan anak jangan sampai terjerat oleh pergaulan yang merusak seperti meminum-minuman keras ataupun main judi, karena judi dan minuman selain merusak kehidupan diri, dapat juga dikategorikan sebagai penyakit masyarakat. Untuk itu orang tua meskipun tetap menerimah keputusan anak akan tetapi tetap mengontrol anaknya. Harapan kebaikanpun tetap tertanam dalam hati orang tua untuk kebaikan anak.Jadi pola pengasuhan premisif orang tua memiliki kehangatan yang cukup,mendukung secara bebas terhadap keinginan anak, tidak mengkomunikasikan peraturan secara jelas dan tidak memaksa anak untuk mematuhinya, membiarkan perilaku anak, memiliki kedisplinan yang tidak konsiten dan tidak menuntut.

\section{Pola Asuh Demoktratis}

Pola asuh demoktratis mengunakan komunikasi dua arah kedudukan antara orang tua dan anak dalam berkomunikasi sejajar. Anak diberi kebebasan yang bertanggung jawab.Orang tua dan anak tidak dapat berbuat semenamena pada salah satu pihak atau kedua belah pihak tidak dapat melaksanakan sesuatu tanpa berkomunikasi terlebih dahulu dan keputusan akhir setujui oleh keduannya tanpa merasa tertekan. Anak diberi kebebasan yang bertanggung jawab.Orang tua menjelaskan hal-hal yang diharapkan dengan konsekuensinya kepada anak.Dapat disimpulkan pola pengasuhan demokratis orang tua memiliki kehangatan, terlibat, menunjukan dukungan dan rasa senang 
terhadap tingkahlaku anak, mempertimbangkan keinginan anak dan mendengarkan pendapat anak, memberikan aternatif pemecahan masalah dan berkomunikasi dengan anak secara jelas. Pola pengasuhan yang paling banyak digunakan oleh orang tua single perentatau janda di Desa Masara Kecamatan Napano Kusambi Kabupaten Muna Barat ada dua tipepola pengasuhan yaitu yang pertamapola pengasuhan demokratisdimana anak diberikebebasan untuk mengungkapkan gagasannya terhadap hal apapun, dan yang kedua pola asuh permisif ini mengunakan komunikasi arah karena meskipun orang tua memiliki kekuasaan penuh dalam keluarga terutama terhadap anak tetapi anak memutuskan apa-apa yang diinginkannya sendiri baik orang tua setuju ataupun tidak.

Faktor Pendorong Dan Penghambat Penerapan Pola Aauh KeluargaSingle Parent Dalam Mendidik Anak Di Desa Masara Kecamatan Napano Kusambi Kabupaten Muna Barat.

\section{Faktor Pendorong}

\section{a) Motivasi Orang Tua}

Motivasi orang tua sangat penting untuk mencapai kesuksesan dalam segala hal, maka pada hakikatnya sangat membutuhkan motivasi dari orang tua atau dorongan yang dapat memberikan semangat pada anakanaknya.Motivasi yang diberikan orang tua dari adanya keinginan untuk meraih sesuatu sehingga anak melakukan segala hal untuk meraih hal tersebut. Sedangkan motivasi dari luar dari dorongan yang diberikan oleh orang lain kepada dirinya sebagai bentuk dukungan dan perhatian kepadanya.Daribeberapahasilwawancaradiatas dapat menunjukkanbahwasanyamotivasi orang tua sangat penting bagi anak-nak walaupun tanpa seorang ayah seorang ibu bisa memberikan motivasi yang lebih baik untuk anak-anaknya walaupun dia seorang single parent.

\section{Faktor Penghambat}

\section{a). Sikap Orang Tua}

Sikap orang tua dalam berinteraksi dengan anak-anaknya. Sikap orang tua ini meliputi cara orang tua memberikan aturan-aturan, hadiah maupun hukuman, cara orang tua menunjukan otoritasnya, dan cara orang tua 
memberikan perhatian serta tanggapan terhadap anaknya. Pendamping orang tua diwujudkan melalui pendidikan cara-cara orang tua orang tua dalam mendidik anaknya. Dari beberepa hasil wawancara menunjukan bawahsannya sikap antara orang tua sengle perent atau seorang janda terhadap anaknya berbeda-beda tetapi tidak semua sikap baik akan ditunjukan oleh orang tua single perent kepada anaknya seperti hasil wawancara tersebut. Tidak bisa di pungkiri kadang orang tua seorang janda (single perent) akan besikap kasar kepada sang anak ketika mereka merasa bahwa sangat sulit untuk mengasuh atau mendidik anak seorang diri ketidaksanggupan inilah yang kadang membuat orang tua terkadang menyerah dan bersikap malas pusing terhadap anakknya.Sehingga terkadang sikap orang tuaterhadap anaknya menjadi salah satu faktor penghambat seorang single perent dalam mendidika anaknya.

\section{b). Perilaku Yang Di Contoh}

Perilaku orang tua janda (single parent) kepada anaknya harus memberi contoh positif dalam mendidik seorang anak karena anak cenderung memperhatikan tingkah laku orang tua atau perilaku mereka. Anak sering menyerap apa yang orang tua lakukan dibandingkan dengan apa yang orang tua katakan. Dalam membimbing atau mendidik seorang anak ibu atau single perent juga menggunakan metode atau cara, agar pendidikan yang diberikan pada anaknya dapat berpengaruh terhadap anak. Dalam membimbing atau mendidik seorang anak setiap orang tua tunggal memiliki metode atau caranya sendiri dalam mendidik anaknya, agar pendidikan yang diberikan pada anaknya dapat berpengaruh terhadap anak. Dari beberepa wawancara menunjukan bawahsannya perilaku orang tua sengle peren tterhadap anaknya berbeda-beda terkadang merekan menunjukan perilaku yang positif agar sang anak dapat mencontoh perilaku orang tua mereka. Tetapi tidak jarang tampa sadar mereka kadang menunjukan sifat negatif yang membuat sang anak terkadang melakukan pelanggaran-pelangaran sepertitidak menghormati orang tua, berkelahi dan lain sebagainnya sampai dengan memberikan hukuman pada anak itu sendiri. Sehingga terkadang perilaku orang tua yang di contoh oleh anak menjadi salah satu faktor penghambat seorang single perent dalam mendidika anaknya. 


\section{c). Kesadaran Diri}

Kesadaran diri harus ditularkan pada anak-anak dengan mendorong meraka agar perilaku kesehariannya taat kepada nilai-nilai moral oleh sebab itu orang tua senantiasa membantu mereka agar mampu melakukan apa saja yang mereka rasa benar dan menyenangkan hati mereka, mengajarkan kepada anak tentang pengendalian yang wajar agar anak tidak tertekan. Memberikan perilaku yang baik dan pantas bagi anak-anaknya, hal ini disebabkan orang tua khususnya, dalam ruang lingkup keluarga merupakan media awal dari suatu proses sosialisasi, sehingga dalam proses sosialisasi tersebut orang tua mencuhrakan perhatinya untuk mendidik anaknya agar menjadi manusia yang baik. Dari beberepa wawancara menunjukan bawahsannya kesadaran orang tua sengle perent terhadap anaknya berbeda-beda terkadang merekan menunyukan perilaku yang positif agar sang anak dapat mencontoh perilaku orang tua mereka. Tetapi tidak semua orang tua single perent mampu menanamkan sikap kesadaran pada diri masing-masing anak-anaknya seperti hasil wawancara tersebut.Tidak bisa di pungkiri kadang orang tua seorang janda (single perent) akan merasa gagal dalam menanamkan kesadaran diri kepada sang anak ketika mereka merasa bahwa sangat sulit untuk mengasuh atau mendidik anak seorang diri sesuai dengan yang dikatakan oleh Efendi dan Susanto (2013) bahwa seseorang dengan kesadaran diri yang tinggi akan mampu memahami kekuatan, kelemahan, nilai dan motif diri dan mampu menerima umpan balik dari orang lain tentang bagaimana memperbaiki secara berkelanjutan.

\section{d). Komunikasi Orang Tua Single Perent Dalam Keluarga.}

Komunikasi yang baik perlu dibangun secara harmonis dalam rangka membangun pendidikan yang baik.Menurut Sri Lestari (2014) komunikasi merupakan aspek yang paling penting. Komunikasi orang tua anak dalam upaya melakukan kontrol, pemantauan, dan dukungan pada anak, tindakan orang tua untuk mengontrol, memantau dapat dipersepsi positif atau negatif oleh anak, oleh karena itu, pengasuhan sangat bergantung pada keterampilan komunikasi berdasarkan pendapat Sri Lestari, bahwa keterampilan dalam berkomunikasi meliputi seperti kecermatan dalam memilih kata, pemilihan kata yang kurang tepat dapat menimbulkan salah persepsi, intonasi dalam 
melakukan komunikasi juga perlu untuk diperhatikan, penekanan pada kata yang berbeda meskipun dalam kalimat yang sama dapat menimbulkan respon perasaan yang berbeda pula. Dari beberepa wawancara menunjukan bawahsannya komunikasi antara orang tua seorang janda atau single perent terhadap anaknya berbeda-beda terkadang mereka menjaga komunikasi dengan anak agar sang anak dapat terbuka denga orang tua merekaketika sang anak sedang dalam masa sulitnya. Tetapi tidak semua komunikasi yang dilakukan oleh orang tua single perent berjalan lancar dalam keluarganya seperti hasil wawancara tersebut. Pada umumnya keluarga orang tua (single perent) dalam hal komunikasi yang dilakukan oleh ibu dananak terlihat kurang terjalin dengan baik, karena ibu yang bekerja menyebabkan minimnya waktu berkomunikasi antara ibu dan anak. Sehingga terkadang komunikasi menjadi salah satu faktor penghambat seorang single perent dalam mendidika anaknya.

\section{PENUTUP}

\section{Kesimpulan}

Berdasarkan hasil dan pembahasanpenelitian ini maka dapat disimpulkan bahwa:Pola asuh keluarga single parent dalam mendidik anak di Desa Masara Kecamatan Napano Kusambi Kabupaten Muna Barat.Pembentukan anak bermula atau berawal dari keluarga.pola asuh orang tua terhadap anakanaknya sangat menentukan dan mempengaruhi keperibadian serta perilaku anak. Anak menjadi baik atau buruk semua tergantung dari pola asuh orang tua dalam keluarga, maka pola asuh dibedakan menjadi beberapa macam yaitu sebagai berikut;

Pola asuh permisif pola asuh anak yang melekat pada single parent ini adalah pola asuh premisif, yang artinya orang tua masih menerimaapa yang menjadi keputusan si anak. Karena tua tau bahwa keputusan anak tentunya mampu membawa dirinya lebih baik.Kepergian seorang ayah bukan satusatunya akhir dari segalanya dalam mendidik anak, ibu bahkan lebih mampu mendidik anak ke hal yang lebih baik tanpa adanya suami, kesendirian seorang ibu bukan kelemahan untuk mendidik melainkan kekuatan untuk mendidik secara mandiri. Pola pengasuhan demokratis orang tua memiliki kehangatan, terlibat, menunjukan dukungan dan rasa senang terhadap tingkah laku anak, 
mempertimbangkan keinginan anak dan mendengarkan pendapat anak, memberikan aternatif pemecahan masalah dan berkomunikasi dengan anak secara jelas. Pola pengasuhan yang paling banyak digunakan oleh orang tua single perent di Desa masara kecamatan kusambi kabupaten muna barat ada dua tipe pola pengasuhan yaitu yang pertama pola asuh permisif orang tua dalam berinteraksi dengan anak untuk melakukan apa yang inggin di lakukan tanpa mempertayakan. pola pengasuhan demokratis dimana anak diberikan kebebasan untuk mengungkapkan gagasannya terhadap hal apapun.

Faktor Pendorong Dan Penghambat Penerapan Pola Asuh KeluargaSingle ParentDalam Mendidik Anak Di Desa Masara Kecamatan Napano Kusambi Kabupaten Muna Barat.

a). Faktor pendorong penerapan pola asuh kelurga single parent dalam mendidik anak di Desa Masara Kecamatan Napano Kusambi Kabupaten Muna Barat yaitu motivasi orang tua

b). Faktor penghambat penerapan pola asuh keluarga single parent dalam mendidik anak di Desa Masara Kecamatan Napano Kusambi Kabupaten Muna Barat yaitu sikap orang tua, perilaku yang di contoh, kesadaran diri, komunikasi.

\subsection{Saran}

1) Bagi orang tua seorang jandadapat lebih bijak dalam mengambil keputusan dan berkepribadian yang tegas agar anak-anak mudah bersosialisasi dengan masyarakat, serta dapat iklas dalam menjalankan hidup dan berusaha untuk mengambil hikmah dari segala proses yang dilalui.

2) Bagi semua elemen lapisan masyarakat sekitar tempat tinggal orang tua seorang janda yaitu di di Desa Masara Kecamatan Napano Kusambi Kabupaten Muna Baratmemberikan bantuan berupa materi dan dukungan sosial kepada orang tua wanita, sebagai sinle parent selain itu, sebaliknya perangkat desa mengajak psikologi dan ahliekonomi menjadi bagian didalamnya untuk memberikan intervensi dalam bentukpelatihan atau seminar gratis bagi wanita kepala keluarga.

3) Bagi anak hendaknya lebih memahami, mengerti dan dapat melihat kondisi orangtuanya. 


\section{DAFTAR PUSTAKA}

Ahriani, A., Agustang, A., Adam, A., Upe, A. (2020). The Multiple Roles of Women in Poor Household in Urban Communities. Journal of Advanced Research in Dynamical and Control Systems. 12 (7), 134-138.

Canete, Jonathan James O. \& Pandey, Digvijay. (2020). The Social Dynamics of Spirituality and Youthfulness: A Social Interplay Between Disposition and Process. Indonesian Journal of Social and Environmental Issues (IJSEI), 1(2), 122-131.

Damsid dan Upe, Ambo. (2010). Asas-Asas Multiple Researches. Yogyakarta: Tiara Wacana.

Duvall, E. M \& Miller, C. M. (1985). Marriage and Family Developmen 6th Ed. New York: Harper \& Row Publishers.

Efendi \& Susanto. (2013). Teori Belajar E Pembelajaran di Sekolah Dasar. Jakarta:

Kencana Prenada Media Grup.

Gunarsa, singgih D. (2008). Psikologi Anak Dan Remaja. Jakarta: PT BPK Gunung Mulia.

Hurlock. (1999). Psikologi Perkembanggan: Suatu Pendekatan Sepanjang Rentang Kehidupan Edisi Kelima (Terjemahan Oleh Istiwidayanti). Jakarta Yayasan Obor Indonesia.

Lee. (1982). Sruktur Interaksi Dan Keluarga. Mineapolis: University Of Minnesta Press.

Minhaturohmah. (2018). Pola Komunikasi Keluarga Single Parent Sebagai Konsekunsi Hasilnya Sosok Ibu Dapartemen Komunikasi. FISIP. 